\title{
Horatius Sinensis
}

\author{
Michael Lackner
}

In terms of sheer quantity, there is still an enormous disproportion between translations from Chinese antiquity into European languages on the one hand and Chinese renderings of European classical antiquity on the other. With dozens of eminent Western specialists in Egyptology, Assyriology, and European classics, the Institute for the History of Ancient Civilizations at Changchun University, established in 1984, has made great efforts to remedy this situation; and Liu Xiaofeng 劉小楓 (born 1956) constantly encourages the teaching of Greek and Latin at the People's University in Peking, where the indefatigable Leopold Leeb is basing his teaching of these languages on his own textbooks that are saturated with Christian literature. However, despite these and other meritorious efforts, this discipline is still rather marginal in China, and the readership is rather small in number. After 1949, the Catholic Fu-jen University moved to Taiwan, and the European classical languages were buried for almost forty years in the mainland.

However, there is a revitalized interest in European antiquity. One of the most prominent scholars for Latin in China is Li Yongyi 李永毅 (born 1975), professor of English (!) at Chongqing University: Chinese owes him the first translation of Catullus' Carmina as well as many other renderings of Latin poetry into Chinese. In an account of his scholarly itinerary, Li also reveals the underlying motivation of his studies:

... this outburst of passion for the Western classics has been parallel to, and following a similar historical logic as, our belated reconciliation with our own ancient tradition. After a century's sterile radical nihilism regarding our heritage, many of us have begun to treat our classics with the respect and care they deserve, refraining from simplified assumptions and searching through painstaking negotiations with the texts for intelligent readings that are relevant both to the original contexts and to our contemporary concerns. Likewise, we believe that it is high time we discarded stereotyped generalizations of Western values, ceasing to take modern Euro-American civilizations as the "medicine" for the "diseases" of an "inherently" defective Chinese culture, a conviction shared by most advocates of the May Fourth Movement in the 1910s and carried to 
catastrophic extremes by the Red Guards half a century later. Studies of Western classics help us understand the roots and ramifications of this drastically different tradition, and reveal ways in which any tradition can be questioned, revised, and transformed in an ongoing dialogue that steers clear of both servile dogmatism and arrogant dismissal. ${ }^{1}$

In his recently published translation Selected Poems of Horace, Li presents us with a bilingual edition of Carminum liber primus (1-9; 11; 14; 17; 20; 22-23; 28; $34 ; 37)$, liber secundus $(2 ; 20)$, liber tertius $(4 ; 30)$, liber quartus $(5 ; 8 ; 12)$, Carmen saeculare, Epodon liber (2;13;60), Sermonum (Satires) liber primus (1-9), liber secundus $(1 ; 3 ; 8)$, Epistularum liber primus $(2 ; 7 ; 19-20)$, and secundus $(1-3$, including the ars poetica). While the translations cover pp. 10-217, the commentaries take up pp. 218-507. With its introduction (life of Horace, an overview of metrics, index, editions, and bibliography), but foremost because of the extensive comments, the volume is also meant as a textbook for advanced students in Latin. The author's secondary sources are limited to English works, but, given the fact that Horace has always been a subject of predilection and sound study in the Anglo-Saxon world, this does not constitute a major shortcoming. It is, however, deplorable, that this laudable translation had to appear in an author's edition, self-published in Middletown, Delaware (June 7, 2019).

Let us first take a look at parts of a translation of a poem by Horace where we can identify some of Li Yongyi's strategies in rendering Horace's verse. We will not retranslate ("re-spell") the entire Chinese translation into English, because there is no need to boast of the faultfinder attitude that is unfortunately so common in translation studies. Here is Carminum liber primus, I, Selected Poems of Horace, 1of:

1 Maecenas atavis edite regibus 麥凱納斯啊, 你, 王族的貴青 (zhòu)

2 o et praesidium et dulce decus meum : 我的堅盾, 甜美榮譽的源頭 (tóu)

3 Sunt quos curriculo pulverem Olympicum 有人癡迷於奧林匹亞的塵霧 (wù)

4 collegisse iuvat metaque fervidis 隨賽車翻卷, 閃電船的輪軸 (zhóu)

5 evitata rotis palmaque nobilis 掠過標錐, 手握光榮的棕櫊 (lü)

6 terrarum dominos evehit ad deos；恍惚間與主幸世界的神交遊 (yóu)

7 hunc, si mobilium turba Quritium 有人寧可讓無常的羅馬庸眾 (zhòng)

8 certat tergeminis tollere honoribus; 簇擁著沿權力之階步步高升; (shēng)

9 illum, si proprio condidit horreo 有人只關心家穀倉的充盈, (yíng)

1 (<https://classicalstudies.org/amphora/new-incarnation-latin-china-yongyi-li>; December 23, 2019). 
10 quicquid de Libycis verritur areis. 不許利比亞的一粒糧食逃遁。(dùn)

11 Gaudentem patrios findere sarculo 手把鋤頭, 農夫怡然耕作 (zùo)

12 agros Attalicis condicionibus 祖先的土地, 阿塔盧斯的財富 (fü)

13 numquam demoveas, ut trabe Cypria 都無法勸他忍受木船的顛箕 (bō)

14 Myrtoum pavidus nauta secet mare; 穿越米爾托捈海, 滿面恐懼。(jù)

15 luctantem Icariis fluctibus Africum 西南風起, 伊卡利亞的波濤 (tāo)

16 mercator metuens otium et oppidi 驚嚇了行商, 閒適靜䍀的故土 (tŭ)

17 laudat rura sui; mox reficit rates 讓他懷念, 但轉眼已修好, (hăo)

18 quassas, indocilis pauperiem pati. 窘迫的生活才是不堪的重負。(fü)

19 Est qui nec veteris pocula Massici 有人不會拒絕老空的誘惑 (hùo)

20 Nec partem solido demere de die 不會因爲虛擲光陰而羞愧, (kùi)

21 spernit, nunc viridi membra sub arbuto 時而在蔥綠的野草樹下安 臥, (wò)

22 stratus, nunc ad aquae lene caput sacrae . 時而傾聽呢喃的神聖泉 水。(shŭi)

23 Multos castra iuvant et lituo tubae 許多人喜歡軍營, 喜歡喇叭 (bā)

24 permixtus sonitus bellaque matribus 與號角齊鳴, 喜歡戰爭, 儘管 (guăn)

25 detestata. Manet sub Iove frigido 母親詛咒它 (ta)。寒冷的天空底 下, (xià)

26 venator tenerae coniugis immemor 獵人守候中夜, 嬌妻拋一邊, (biān)

27 seu visa est catulis cerva fidelibus, 或者鹿被忠臣的狗發現 (xiàn), 或者

28 seu rupit teretes Marsus aper plagas 野猪掙破了網, 在馬爾西山 間。(jiàn)

29 Me doctarum hederae praemia frontium 我因爲獎賞詩人的春藤束 (shù)

30 dis miscent superis; me gelidum nemus 而置身的上界; 冰涼的樹 林, (lín)

31 Nympharumque leves cum Satyris chori 水澤仙女和山神的輕盈歌舞 (wŭ)

32 secernunt populo, si neque tibias 分開了我和眾人, 既然笛音 (yīn)

33 Euterpe cohibet nec Polyhymnia 歐忒耳佩不禁止, 聖歌之主 (zhŭ)

34 Lesboum refugit tendere barbiton. 也願意彈奏萊斯博斯的里拉琴。( qín)

35 Quodsi me lyricis vatibus inseres, 但你若給我抒情詩人的冠冕, (miăn)

36 Sublimi feriam sidera vertice. 我高昂的頭將立於群星之巔。(diān)

Notwithstanding the above-mentioned caveat, some remarks about the general strategy of the translator still seem to be appropriate. There is no need to explain "Lybia" (line 10), but the "Quirites" (line 7) have been rendered as "the ordinary people of Rome," and the "pocula Massici" (line 19) are transformed into "wine of old cellars"; the same device is used for "Polyhymnia" (line 33), 
which appears as "the mistress of sacred songs." Again, in lines 7 and 8, we find an allusion to the three highest offices of Rome - tergeminis honoribus-(aedile, praetor, consul), which, in Chinese, find its metamorphosis as "they ascend the ladder of power step by step."

What seems to be more important is a structural transformation of the poem for the sake of its euphony in Chinese. There is no doubt that in this poem dedicated to Maecenas, Horace maps out different life designs, which, at the end, are juxtaposed in opposition to his own choice to be a poet. And there is also no doubt that each of these life designs constitutes a separate unit of meaning. Chinese poetry is unable to emulate metrics (and this is how the "regulated verse poem," lüshi 律詩, evolved), but it does have rhymes. Li Yongyi's ingenious method in translating the first poem of Carminum liber primus consists in denoting each of the units of meaning by a sequence of rhymes, predominantly end-rhymes, with some few internal rhymes. Just let a Chinese native speaker read this text aloud, and you will immediately become aware of the translation's beauty and the intrinsic logic that delineates the units of meaning.

However, the translation's rhyme scheme follows Li's own understanding of coherent units of meaning: Lines 1-6 constitute a unit, and again 7-10; such is the case for lines 11-18, 19-22, 23-25 (with an internal rhyme 叭/它 $b \bar{a} / t a$ as well as an end rhyme 叭/下xià), and 26-28. Lines 29-34 introduce the poet's position and lines $35^{-36}$ return, yet with another rhyme scheme, to Maecenas' benevolence. One could arguably object to this arrangement, which is also emphasized by the frequent repetition of you ren 有人, "there are those who..." (which occurs only once in the Latin text: "sunt quos...") to mark the different life designs. But notwithstanding possible criticism, Li Yongyi has magnificently succeeded in making the poem sound alive for a native speaker of Chinese.

There are, however, obstacles in translating poetry of European antiquity into Chinese. In an article published in 2001, Christoph Harbsmeier has pointed to the fact that classical ("pre-buddhist") Chinese lacked a "parenthetic mode." ${ }^{2}$ Harbsmeier provides us with examples like "horresco referens ('I am horrified to report'), vel potius dicam ('or rather should I say', as a form of selfcorrection inserted in the text), ... ut ita dicam ('so to speak,' creating a distance between themselves and their present manner of expression") and many other rhetorical forms ("metalinguistic modes") that were not part of what he calls the "cultural style" of classical Chinese. According to Harbsmeier, the syntactic

2 Harbsmeier, "May Fourth Linguistic Orthodoxy and Rhetoric: Some Informal Comparative Notes," in New Terms for New Ideas: Western Knowledge and Lexical Change in Late Imperial China, ed. Michael Lackner, Iwo Amelung, and Joachim Kurtz (Leiden: Brill, 2001), 373-410. 
repertoire of classical Chinese could have expressed such modes of subjectivity, but it was rather "culture" than "language" that prevented their emergence.

However, even modern Chinese has difficulties in rendering this kind of rhetoric. A close look at some of the translations will enable us to see how $\mathrm{Li}$ Yongyi tries to circumvent the pitfalls of the subjective character of the "parenthetic mode" in his native tongue. And in the examples quoted below, we will have to recur to re-translations from the Chinese to elucidate the translator's skill and awareness, because his commentaries reveal that he is completely cognizant of the original version's rhetorical structure and intention. ${ }^{3}$

How, for instance, to translate vellem in Satires 3, Selected Poems of Horace, 96?:

Vellem in amicitia sic erraremus, et isti

Errori nomen virtus posuisset honestum. ${ }^{4}$

(I wished we erred in the same way with regard to friendship, and that virtue had affixed a reputable appellation to such an error).

We know that vellem refers to an unrealizable wish and therefore the subjunctive past tense is used. The Chinese translation reads:

\section{我真心盼望, 我們對朋友也能這樣 犯錯，美德能給它一個光榮的名字.}

(I truly hope we could err the same way with regard to our friendship, and that virtue could give it a glorious name).

The translator is fully aware of the problem of rendering the expression of an unrealizable wish into Chinese: on p. 329, he comments on line 41: "vellem (我 希望）的未完成過去時虛擬式表明這個希望無法實現, vellem (I hope) is

3 If not indicated otherwise, I have concocted all English translations from Horace by using more than a dozen existing translations, which do not need to be enumerated here. My translations merely serve to provide the reader with a first impression of the meaning, and they are adapted, as far as possible, to Li Yongyi's renderings. However, to provide the reader with an orientation aid, the Loeb Classical Library translation will be quoted for each passage. There are some astonishing observations to be made!

4 Horace: Satires, Epistles, Ars Poetica; With an English Translation by H. Rushton Fairclough. (Cambridge, Mass.: Harvard Univ. Press, 1942 [1st ed. 1926], Loeb Classical Library; henceforth Loeb). Loeb, 35: "I could wish that we made the like mistake in friendship and that to such an error our ethics had given an honourable name." 
imperfect subjunctive and indicates that this wish cannot be realized"). The comment thus clarifies what the translation had to leave out.

Let us now take a look at an authentic parenthesis, as it occurs in Satires 2:1, lines 44f., Selected Poems of Horace, 13of.):

At ille qui me commorit - melius non tangere! clamo-flebit, et insignis tota cantabitur urbe. ${ }^{5}$

(But he who provokes me (better not touch, I cry!) will suffer, and his blemishes will be sung throughout the City).

The Chinese translation has:

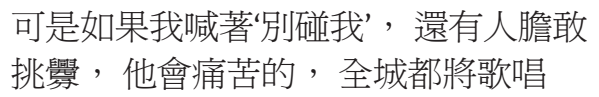

(But if I shout "don't touch me," there is still someone who will courageously provoke, but he will cry bitterly, and the whole city will praise his reputation).

No doubt the parenthetical interjection is missing in the Chinese version. But, again, the commentary (p.379) clarifies: “melius non tangere 最好別磁（我） (best is not to touch一me一, melius 更好, 意爲不碰是“更好” 的選擇 melius, 'better,' means that not touching is the 'better' choice. Clamo, 我喊, 賀拉斯已 經提前發出警告。Horace has already issued this warning in advance.”

In this case, the parenthesis points to a "warning in advance," how nicely articulated!

Satires 1:1, lines 15-17, Selected Poems of Horace, 8 o has:

Si quis deus, 'En ego' dicat,

iam faciam quod voltis: eris tu, qui modo miles, mercator; tu, consultus modo, rusticus. ${ }^{6}$

5 Loeb, 131: "But if one stir me up ('Better not touch me!' I shout), he shall smart for it and have his name sung up and down the town."

6 Loeb, 5, 7: "If some god were to say: 'Here I am! I will grant your prayers forthwith. You, who were but now a soldier, shall be a trader; you, but now a lawyer, shall be a farmer." 
(If any god should say, "Behold! I will effect what you desire: you, that were just now a soldier, shall be a merchant; you, lately a lawyer [shall be] a farmer).

In Li Yongyi's Chinese we have:

倘若某位神在空中宣布,

瞧！我成全你們的願望。士兵, 你

變成行商; 律師, 你變成農夫。

If any god in the sky declared:

Look! I fulfill your wishes. Soldier, you

Become merchant; lawyer, you become peasant.

The subjunctive of 'dicat' may be satisfactorily rendered by "if" (although the commentary on p. 308 remarks that 'dicat' [說] by its subjunctive form indicates a hypothetical mode [假想] ) , but the modo ... modo, which the translation ignores is explained as 剛才, “a moment ago," 後面省略了”and the 'eris' is omitted").

Similarly, Satires 1:3, line 19, Selected Poems of Horace, 94:

Nunc aliquis dicat mihi: Quid tu? ${ }^{7}$

(Now someone might say to me: what about you?)

In Li Yongyi's Chinese:

有人對我說：你呢？

(someone says to me: and you?)

Commentary, p. 327: “Nunc aliquis dicat mihi 在這個節骨眼上, 某人（可能 會) 對我說, dicat 的虛擬式表示潛在可能。(At this juncture, someone [possibly could] say to me; the subjunctive of 'dicat' indicates the latent possibility)."

No "latent possibility" (someone who possibly could) is to be found in the translation, so we may conclude that the translator had to avoid this phrasing-simply because it sounds too clumsy in the Chinese.

7 Loeb, 35: "Now someone may say to me: 'What about yourself?" 
In Satires, 1:1, line 23ff., Selected Poems of Horace, 8o, we find:

Preaterea, ne sic, ut qui iocularia, ridens

Percurram, (quamquam ridentem dicere verum quid vetat?) ${ }^{8}$

(But further, that I may not run over this in a laughing manner, like those [who treat] on ludicrous subjects [though what hinders one being merry, while telling the truth?])

In the Chinese:

\section{可是, 我不打算像逗樂的人那樣 一直戲謔下去-不過笑著說真相 又犯了什麼戒?}

(But I do not intend to ridicule this like people who clown around-however, telling the truth while laughing, where is the transgression?)

Commentary, p. 308: “quamquam, 雖然, 引導讓步狀語從句。Quamquam introduces a concessive adverbial clause. 現在分詞賓格ridentem (笑著)修飾 dicere 說出隱含的主語。Now the participle 'ridentem' in the accusative case modifies the hidden nominative of dicere. Verum 真相, 真理 作 'dicere' 的賓 語, Verum 'truth' is the object of 'dicere' 整個不定式短語作下一行 'vetat' 禁 止阻礙的賓語。And the entire infinitive phrase is the object of 'vetat' in the following line."

Even the slightest details of Horace's rhetorical devices are acknowledgedin the commentary; but, in the translation, the translator has to shy away from rendering justice to the idea of an intersection.

And in Ars poetica, lines 42-44, Selected Poems of Horace, 196, we find:

Ordinis haec virtus erit et venus, aut ego fallor, ut iam nunc dicat iam nunc debentia dici. ${ }^{9}$

(This, or I am mistaken, will constitute the merit and beauty of arrangement, that the poet just now says what just now ought to be said).

8 Loeb, 7: "Furthermore, not to skim over the subject with a laugh like a writer of witticismsand yet what is to prevent one from telling truth as he laughs...."

9 Loeb, 453: "Of order, this, if I mistake not, will be the excellence and charm that the author of the long-promised poem shall say at the moment what at that moment should be said." 
In Chinese we have:

\section{如果我理解正確，佈局的優點和妙處} 就在於：創作承諾的作品時

(If I understand this correctly, the virtue and the subtlety of a composition just lie in the moment of creative commitment of the literary work.)

The commentary (p. 474) explains: “aut ego fallor,” 或者我被欺騙了，意爲“如 果我沒有說錯的話' If I am not deceived, meaning, 'If I haven't said something wrong."

Most probably, expressions like "aut ego fallor" or "nisi fallor" (If I am not mistaken) can be found nowhere in texts of ancient China. But even in modern Chinese they seem to constitute an almost insurmountable hurdle. "If I understand this correctly" is a far cry from the extremely self-relativizing "aut ego fallor."

Consider then Epistularum liber secundus, 1, line 210, Selected Poems of Horace, 179:

Ille per extentum funem mihi posse videtur

Ire poeta, meum qui pectus inaniter agit. ${ }^{10}$

(That poet seems to me the one who goes through great difficulties and by his fictions provokes my heart).

In Li Yongyi's Chinese this is:

\section{告訴你, 我心目中高超的詩人是什麼樣子： \\ 他讓我的心爲虛構的世界感覺痛苦}

(I tell you: the excellent poet in my mind's eye allows my heart the fictional sentiment of this world's grief ).

Commentary, p. 449: "ille per extentum funem mihi posse videtur ire poeta, 那位詩人（那樣的詩人, 具體見下文）在我看來能夠在繃緊的繩子上行 走', 意哌我認爲他技巧高超, 就像雜技演員。不定式 posse...ire 與 videtur (他看起來) 連用. That poet—see below-is in my view able to walk on a rope,

10 Loeb, 415 : “... methinks that poet is able to walk a tight rope, who with airy nothings wrings my heart." 
meaning I think his skill is excellent, like a circus performer. The infinite posse...ire are connected with videtur (he seems to)."

With some clemency, one could accept that in this case, "my mind's eye" stands for "videtur." However, the commentary makes clear that "videtur" poses a problem, otherwise one would not need the literal Chinese translation as 看起來, "he seems to."

Next, Epistularum liber secundus, 2, line 52-54, Selected Poems of Horace, 186:

Sed quod non desit habentem

Quae poterunt umquam sais expurgare cicutae, ni melius dormire putem quam scribere versus? ${ }^{11}$

(Could it ever be sufficient to purify my mind, if I didn't think dozing were better than writing poetry?)

In Chinese we have:

...如果我寧可寫詩, 也不選擇睡眠?

(If I can better write poetry, and have not chosen to sleep?)

Commentary, p. 458, says: 如果我不認爲睡眠比寫詩好 (If I didn't think sleeping were better than writing poetry).

Let us note the occurrence of 認爲 (think, consider) throughout the commentary. Once again, we may observe that, for a Chinese reader, the repetitive occurrence of 我認爲 (I think, I consider, I assume) may sound clumsy.

Finally, Epistolarum liber secundus, 2, line 17, Selected Poems of Horace, 184:

Ille ferat pretium, poenae securus, opinor. ${ }^{12}$

(he will get his price without fear of penalty, I think).

The Chinese says:

我認爲他會得到報的價, 而不受懲罰。

11 Loeb, 429: "But now that I have sufficient store, what doses of hemlock could ever suffice to cleanse my blood, if I were not to think it better to slumber than to scribble verses?"

12 Loeb, 425: “... the seller, I take it, would get his price without fear of penalty." 
(I think he will obtain the price and will not receive a punishment).

Commentary, p. 455: “opinor, 我認爲, 插入語 'opinor,' I consider, parenthesis."

In this case, the commentary simply admits the impossibility of rendering the " parenthesis" into proper Chinese.

\section{Conclusion}

Through an intrinsically Chinese poetic device, the rhyme, Li Yongyi tries to do justice to the beauty of Horace's verses. The careful choice of words (which in this contribution has not been addressed) and the entire rhythm of his translation make the Selected Poems of Horace a masterpiece of transcultural conveyance. The parenthetic, subjective style of the Latin original is acknowledged throughout the commentary, but the translation meticulously avoids its literal rendering because of the fear of sounding too clumsy. And, in fact, if the translation would follow the conscientious remarks of the commentary, readers would certainly not be able to fully enjoy the charm of the original. There remains, of course, the intriguing question of whether modern Chinese is a genuinely apt medium for (translating) poetry, but this is a different matter and is not the subject of the present contribution.

\section{Epilogue}

However, there is more to overcome than mere linguistic barriers. Let us take a brief look at cultural (non-linguistic) barriers:

Satires, I, 2, Selected Poems of Horace, 127:

... ne, dum futuo, vir rure recurrat. ${ }^{13}$

Although the author does not shy away from translating the somewhat less puritan satire I, 2, , «futuo» (no translation needed, sapienti sat) is translated by «intercourse» 交 and explained (in the commentary, p. 325) as «describing the sexual action of a man towards a woman» 描述男人對女人的性動作. No doubt there are definitely more literal words in Chinese for this verb. In this

13 Loeb, 29: "No fears have I in her company, that a husband may rush back from the country." This translation is far more puritan than Li Yongyi's! 
case, the translator did not expect the readers to put up with the lewd wording of the original. ${ }^{14}$

However, there you go: Satires I, 2, lines 116f., Selected Poems of Horace ,90:

Tument tibi cum ingenua, num, si

Ancilla aut verna est praesto puer, impetus in quem

Continuo fiat, malis tentigine rumpi? ${ }^{15}$

(When your prick swells, then, and a young slave girl or boy's nearby you could take. At that instant, would you rather burst with desire? $)^{16}$

In Chinese we have:

性器鼓脹時 (when the genital organ swells)，如果身邊就有妓女， 或年少的奴隸, 可以發洩你的欲火 (give vent to your burning desire)

In this case, the literal translation leaves nothing to be desired.

14 <https://www.poetryintranslation.com/PITBR/Latin/HoraceSatiresBkISatII.php\#an chor_Toc98155411>; December 23, 2019)

15 Loeb, 29: "When your passions prove unruly, would you rather be torn with desire?" See n. 13 .

16 <https://www.poetryintranslation.com/PITBR/Latin/HoraceSatiresBkISatII.php\#an chor_Toc98155411> (December 23, 2019). 